\title{
Vantagem em casa no campeonato brasileiro de futebol: efeito do local do jogo e da qualidade dos times
}

\author{
Home advantage in the Brazilian soccer championship: effect \\ of game location and team quality
}

\author{
Cristiano Diniz da Silva \\ Nísio Cunha Medeiros 2 \\ Ana Cristina Diniz da Silva 3
}

1 Universidade Federal de Viçosa. Programa de Pós-graduação em Educação Física. Viçosa, MG. Brasil. Bolsista CAPES. Brasil.

2 Universidade Federal de Viçosa. Especialização em Futebol. Viçosa, Minas Gerais, Brasil.

3 Universidade Federal de Viçosa. Laboratório de Performance Humana. Viçosa, MG. Brasil.

Recebido em 08/10/08 Revidado em 21/12/08 Aprovado em 12/05/09
Resumo - O propósito do presente estudo foi verificar a vantagem em casa, considerando a interferência e interação entre local do jogo e qualidade dos times nos aproveitamentos percentuais de vitórias e empates no futebol brasileiro. Dados de 10 anos (1998-2007) do Campeonato Brasileiro da primeira divisão foram considerados, totalizando 3.836 partidas. Para qualificação dos clubes, foi utilizado o primeiro desvio da Curva de Gauss em relação à pontuação obtida, sendo superior a este desvio será classificada como de Alta Qualidade (AQ), entre eles como Média Qualidade (MQ) e inferior como Baixa Qualidade (BQ). Foi observado que houve efeito do local do jogo $\left(\mathrm{p}<0,001 ; \eta^{2}=0,88\right)$; os clubes venceram, em média, $25 \%$ a mais jogando em casa do que fora. Esse efeito foi menos pronunciado para os times $\mathrm{BQ}$, em relação aos MQ e AQ ( $<<0,001)$, com significante efeito do fator qualidade também $\left(\eta^{2}=0,89\right)$. Foi notada interação significante, porém de média força, entre os fatores qualidade vs local do jogo, no aproveitamento de vitórias em casa $\left(\mathrm{p}=0,023 ; \eta^{2}=0,13\right)$. Houve significante relação entre o local do jogo vs qualidade dos clubes para empates $(\mathrm{p}<0,001$; $\eta^{2}=0,39$ ), sem nenhuma influência importante desses fatores isoladamente. Os times AQ empatam menos em casa do que fora, enquanto o inverso aconteceu para os clubes BQ $(p<0,05)$. Não houve diferença de empates em casa e fora para os times MQ. Conclui-se que o fator local do jogo pode ser atributo de vantagem nos confrontos do Campeonato Brasileiro de futebol da primeira divisão, sendo mais pronunciada quando a qualidade do clube é maior.

Palavras-chave: Vantagem em Casa; Futebol; Campeonato Brasileiro; Local de Jogo; Qualidade de Time; Atletas.

Abstract - The objective of the present study was to evaluate home advantage in Brazilian soccer considering the interference of and interaction between game location and team quality in the percentage of wins and draws. Data from the Brazilian first-division soccer championship comprising a period of 10 years (1998-2007) were analyzed, for a total of 3,836 games. For club qualification the first deviation of the curve of Gauss was used in relation to the punctuation obtained. Clubs presenting a punctuation higher than this deviation were classified as high quality (HQ), clubs with an intermediate punctuation as average quality (AQ), and clubs with a lower puncutation as low quality (LQ). There was an effect of game location $\left(p<0.001 ; \eta^{2}=0.88\right)$, with clubs playing at home winninng on average $25 \%$ more games. This effect was less pronounced for $L Q$ teams compared to AQ and HQ teams ( $p<0.001)$, a finding indicating a significant effect of team quality $\left(\eta^{2}=0.89\right)$. A significant, although of medium strength, interaction was observed between team quality and game location for the percentage of wins at home $\left(p=0.023 ; \eta^{2}=0.13\right)$. There was also a significant relationship between game location and team quality for draws $\left(p<0.001 ; \eta^{2}=0.39\right)$, with no important influence of the individual factors. HQ teams presented fewer draws at home than away, while the opposite was observed for LQ clubs $(p<0.05)$. No difference between draws at home and away was observed for AQ teams. In conclusion, game location is an advantageous factor in Brazilian first-division soccer championship games, with this factor being more pronounced in the case of high quality teams.

Key words: Home advantage; Soccer; Brazilian championship; Game location; Team quality; Athlete. 